\title{
Asymmetric Halogeno-Bridged Complexes of the Late Transition Metals - A Computational and Experimental Study
}

\author{
Margarita Öhm, ${ }^{[\mathrm{a}]}$ Axel Schulz, ${ }^{*[a]}$ and Kay Severin*[a]
}

\author{
Keywords: Density functional calculations / Dinuclear complexes / Bridging ligands / Transition metals / halides
}

\begin{abstract}
Metathesis reactions of dinuclear halo-bridged complexes of the late transition metals have been studied by NMR. For selected combinations of 15 different complexes, it has been shown that asymmetric complexes are formed in a dynamic equilibrium. The equilibrium constants have been calculated and the trends therein are discussed. A theoretical analysis of halo-bridged complexes containing $\left(\mathrm{C}_{3} \mathrm{H}_{5}\right) \mathrm{MX},\left(\mathrm{H}_{3} \mathrm{P}\right) \mathrm{MX}_{2}$
\end{abstract}

$\left[\left(\mathrm{H}_{3} \mathrm{P}\right)_{2} \mathrm{MX}\right]^{+}$, and (ppy) ${ }_{2} \mathrm{RhCl}$ fragments $(\mathrm{M}=\mathrm{Pd}, \mathrm{Pt} ; \mathrm{X}=\mathrm{Cl}$, $\mathrm{Br}, \mathrm{I}_{i}$ ppy = anion of 2-phenylpyridine) has been carried out to gain further insight into (i) the influence of the bridging halogen atoms on the equilibrium, (ii) the electron transfer, (iii) the thermodynamic stability and the dynamic equilibrium behaviour, and (iv) structural differences between symmetric and asymmetric halo-bridged complexes.

\section{Introduction}

Dinuclear complexes in which two identical metal fragments are connected through halo bridges are versatile starting materials in organometallic chemistry. They readily react with neutral or anionic ligands to form mononuclear complexes. Due to their intrinsic reactivity, they are often used as catalyst precursors. Asymmetric complexes on the other hand, i.e. complexes in which two different metal fragments are joined through halo bridges, have been described only rarely. ${ }^{[1]}$ The reactivity of this class of compounds has just started to be explored. Grubbs and coworkers have reported that asymmetric complexes such as $\mathbf{1}$ are extremely active catalysts for alkene metathesis, being more active than the original "Grubbs catalyst" $\left[\left(\mathrm{PCy}_{3}\right)_{2} \mathrm{Ru}(=\mathrm{CHPh}) \mathrm{Cl}_{2}\right]^{\left[{ }^{2]}\right.}$ Furthermore, it has been shown that the activity is modulated by the second metal fragment, which itself is catalytically inactive. Similar results have been obtained by Herrmann and co-workers, who have investigated catalysts such as $2 .^{[3]}$ These findings clearly show that asymmetric chloro-bridged complexes are an interesting class of compounds, among which highly active catalysts showing co-operative effects between the two metal centres can be found.

In previous publications, we have reported that in some cases heterobimetallic and mixed-valence chloro-bridged complexes can be obtained in almost quantitative yield by metathesis reactions of the appropriate symmetrical complexes. ${ }^{[4]}$ This kind of reaction has provided easy access to a variety of different complexes, several of which have been structurally characterized. In this paper, we provide experimental evidence that halo-bridged complexes of the late transition metals generally undergo metathesis reactions with one another. In chlorinated organic solvents, an equi-

[a] Institut für Anorganische Chemie der Ludwig-MaximiliansUniversität,

Butenandtstraße 5-13, 81377 München, Germany

E-mail: kse@cup.uni-muenchen.de

lex@cup.uni-muenchen.de librium between symmetrical and asymmetrical halobridged complexes is rapidly established (Scheme 1). Factors determining the position of this equilibrium are discussed herein. The experimental results have been supplemented by a computational study, performed to gain further insight into the stabilities, electronic character, and structural features of asymmetric halo-bridged complexes.

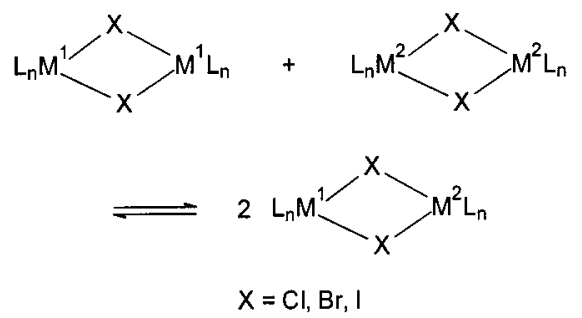

Scheme 1

\section{Results and Discussion}

\section{NMR Studies}

The mixed-valence complex $\left[(\mathrm{azb})_{2} \mathrm{Rh}(\mu-\mathrm{Cl})_{2} \mathrm{Rh}(\mathrm{CO})_{2}\right]$ $(\mathrm{azb}=$ ortho-metallated azobenzene) (3) was among the first asymmetric chloro-bridged complexes to be isolated ${ }^{[5]}$ and structurally characterized. ${ }^{[6]}$ Although other methods of preparation were initially investigated, it was realized that this compound could also be obtained by metathesis of $\left[(\mathrm{azb})_{2} \mathrm{Rh}(\mu-\mathrm{Cl})\right]_{2}$ with $\left[(\mathrm{OC})_{2} \mathrm{Rh}(\mu-\mathrm{Cl})\right]_{2}{ }^{[5 \mathrm{cc}]}$ The first systematic analysis concerning the dynamic behaviour of chloro-bridge metathesis was carried out by Masters and co-workers. ${ }^{[7]}$ They studied the reaction of $\left[\left(\mathrm{R}_{3} \mathrm{P}\right) \mathrm{ClPd}(\mu-\right.$ $\mathrm{Cl})]_{2}$ with $\left[\left(\mathrm{R}_{3} \mathrm{P}\right) \mathrm{ClPt}(\mu-\mathrm{Cl})\right]_{2}(\mathrm{R}=\mathrm{Pr}, \mathrm{Bu})$ in chloroform by means of ${ }^{31} \mathrm{P}$ NMR. The two symmetrical complexes were shown to be in a dynamic equilibrium with the heterobimetallic compound $\left[\left(\mathrm{R}_{3} \mathrm{P}\right) \mathrm{ClPd}(\mu-\mathrm{Cl})_{2} \mathrm{PtCl}\left(\mathrm{PR}_{3}\right)\right]$. In contrast to the above-mentioned rhodium complex, only a slight thermodynamic preference for the asymmetric complex was observed $(K=5.3$ for $\mathrm{R}=\mathrm{Bu})$. These results were later confirmed by Clark and co-workers, who also carried 

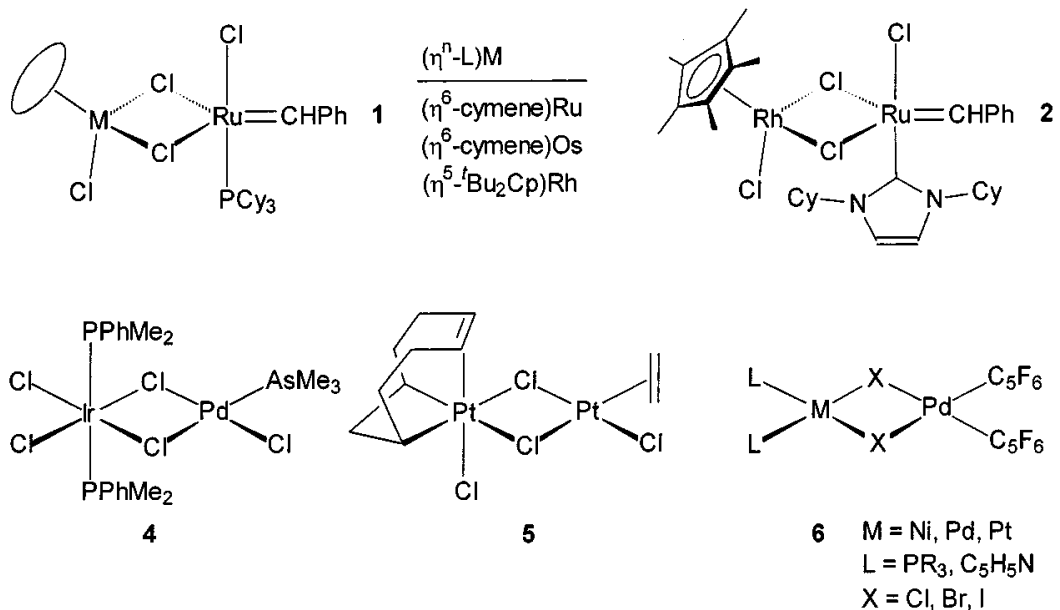

out a crystal structure analysis of $\left[\left(\mathrm{Et}_{3} \mathrm{P}\right) \mathrm{ClPd}(\mu-\right.$ $\left.\mathrm{Cl})_{2} \mathrm{PtCl}\left(\mathrm{PEt}_{3}\right)\right]^{[8]}$ In recent publications, we have reported on investigations of the reactions of $\left[\left(\mathrm{C}_{10} \mathrm{H}_{16}\right) \mathrm{ClRu}(\mu-\mathrm{Cl})\right]_{2}$, $\left[\left(\mathrm{R}_{3} \mathrm{P}\right)_{2} \mathrm{M}(\mu-\mathrm{Cl})\right]_{2}\left(\mathrm{BF}_{4}\right)_{2}(\mathrm{M}=\mathrm{Pd}, \mathrm{Pt})$, and [("N-C" $)_{2} \mathrm{M}(\mu-$ $\mathrm{Cl})]_{2}(\mathrm{M}=\mathrm{Rh}$, Ir; "N-C" = 2-phenylpyridine anion, benzo[ $h]$ quinoline anion) with various chloro-bridged complexes of the late transition metals. ${ }^{[4]}$ In almost all cases, the corresponding asymmetric complexes were found to be formed in virtually quantitative yields $(K>100)$. In order to gain further insight into the scope and limitations of metathesis as a method for preparing asymmetric dinuclear complexes, we have now performed a comprehensive NMR study with selected combinations of 15 different halobridged complexes of the late transition metals. ${ }^{[9]}$ Equimolar amounts of two symmetrical complexes were dissolved in $\mathrm{CDCl}_{3}$ or $\mathrm{CD}_{2} \mathrm{Cl}_{2}$. An approximation of the equilibrium constant was then determined by integration of suitable NMR signals. The results, supplemented by data from the literature, are summarized in Table 1.
In all cases, asymmetric halo-bridged complexes could be detected by NMR. Side reactions or mononuclear species were not observed. The temperature-independent equilibrium distribution was reached within seconds and remained constant thereafter. For some complexes, dynamic behaviour led to significant line broadening at room temperature. Therefore, the spectra were generally recorded at temperatures below $0{ }^{\circ} \mathrm{C}$. Depending on the symmetry of the dinuclear product, two different dynamic processes responsible for line broadening can be distinguished. Firstly, the complexes $\left[(\mathrm{dmb}) \mathrm{Pd}(\mu-\mathrm{Cl})_{2} \mathrm{MCl}\left(\mathrm{PBu}_{3}\right)\right](\mathrm{M}=\mathrm{Pd}, \mathrm{Pt}$; Table 1, Entries 5 and 11) exist as mixtures of two isomers. For $\left[(\mathrm{dmb}) \mathrm{Pd}(\mu-\mathrm{Cl})_{2} \mathrm{PdCl}\left(\mathrm{PBu}_{3}\right)\right]$, the interconversion of these isomers is fast compared to the NMR time scale (Scheme 2). From the coalescence temperature $T_{\mathrm{c}}$ and the difference in chemical shifts of the ${ }^{31} \mathrm{P}$ NMR signals, a $\Delta G^{\ddagger}$ value of $14.0( \pm 0.2) \mathrm{kcal} / \mathrm{mol}$ was calculated. ${ }^{[10]}$ Interestingly, for the corresponding platinum complex $[(\mathrm{dmb}) \operatorname{Pd}(\mu-$ $\left.\mathrm{Cl})_{2} \mathrm{PtCl}\left(\mathrm{PBu}_{3}\right)\right]$, a coalescence of the ${ }^{31} \mathrm{P}$ NMR signals was

Table 1. Equilibrium constants together with selected NMR data for asymmetric halo-bridged complexes

\begin{tabular}{|c|c|c|c|c|}
\hline Entry & Complex & ${ }^{31} \mathrm{P}$ NMR $[\mathrm{ppm}]$ & Temp. $\left[{ }^{\circ} \mathrm{C}\right]$ & $K$ \\
\hline 1 & {$\left[\left(\mathrm{C}_{3} \mathrm{H}_{5}\right) \mathrm{Pd}(\mu-\mathrm{I})_{2} \mathrm{PdI}\left(\mathrm{PEt}_{3}\right)\right]$} & 46.23 & -40 & $0.2 \cdot 10^{-1}$ \\
\hline 2 & $\left.\left[\mathrm{C}_{3} \mathrm{H}_{5}\right) \mathrm{Pd}(\mu-\mathrm{Br})_{2} \mathrm{PdBr}\left(\mathrm{PEt}_{3}\right)\right]$ & 42.60 & -40 & $0.8 \cdot 10^{-1}$ \\
\hline 3 & {$\left[\left(\mathrm{C}_{3} \mathrm{H}_{5}\right) \mathrm{Pd}(\mu-\mathrm{Cl})_{2} \mathrm{PdCl}\left(\mathrm{PEt}_{3}\right)\right]$} & 46.00 & -40 & $1.2 \cdot 10^{-1}$ \\
\hline 4 & {$\left[(\operatorname{cod}) \mathrm{Rh}(\mu-\mathrm{Cl})_{2} \mathrm{PdCl}\left(\mathrm{PBu}_{3}\right)\right]^{\mathrm{a}]}$} & 38.70 & -40 & $1.5 \cdot 10^{-1}$ \\
\hline 5 & {$\left[(\mathrm{dmb}) \mathrm{Pd}(\mu-\mathrm{Cl})_{2} \mathrm{PdCl}\left(\mathrm{PBu}_{3}\right)\right]^{[\mathrm{b}]}$} & $37.50 ; 37.66(10: 16)$ & -40 & $2.4 \cdot 10^{-1}$ \\
\hline 6 & {$\left[\mathrm{Cp} * \mathrm{Cl} \operatorname{Ir}(\mu-\mathrm{Cl})_{2} \mathrm{Pd}\left(\mathrm{C}_{3} \mathrm{H}_{5}\right)\right]$} & - & -40 & $2.7 \cdot 10^{-1}$ \\
\hline 7 & {$\left[\mathrm{Cp} * \mathrm{ClRh}(\mu-\mathrm{Cl})_{2} \mathrm{Pd}\left(\mathrm{C}_{3} \mathrm{H}_{5}\right)\right]$} & - & -40 & $4.8 \cdot 10^{-1}$ \\
\hline 8 & {$\left[\right.$ (cymene) $\left.\mathrm{ClRu}(\mu-\mathrm{Cl})_{2} \mathrm{Pd}\left(\mathrm{C}_{3} \mathrm{H}_{5}\right)\right]$} & - & -40 & $5.1 \cdot 10^{-1}$ \\
\hline 9 & {$\left[\left(\mathrm{C}_{3} \mathrm{H}_{5}\right) \mathrm{Pd}(\mu-\mathrm{Cl})_{2} \mathrm{PtCl}\left(\mathrm{PEt}_{3}\right)\right]$} & 6.61 & -40 & $8.8 \cdot 10^{-1}$ \\
\hline 10 & {$\left[\left(\mathrm{C}_{3} \mathrm{H}_{5}\right)_{2} \mathrm{Rh}(\mu-\mathrm{Cl})_{2} \mathrm{PdCl}\left(\mathrm{PBu}_{3}\right)\right]$} & 35.01 & -40 & 1.2 \\
\hline 11 & {$\left[(\mathrm{dmb}) \mathrm{Pd}(\mu-\mathrm{Cl})_{2} \mathrm{PtCl}\left(\mathrm{PBu}_{3}\right)\right]^{[\mathrm{b}]}$} & $\begin{array}{l}0.15\left({ }^{1} J_{\mathrm{PtP}}=3728 \mathrm{~Hz}\right) \\
0.38\left({ }^{1} J_{\mathrm{PtP}}=3686 \mathrm{~Hz}\right)(15: 10)\end{array}$ & -40 & 1.3 \\
\hline 12 & {$\left[(\operatorname{cod}) \mathrm{Rh}(\mu-\mathrm{Cl})_{2} \mathrm{PtCl}\left(\mathrm{PBu}_{3}\right)\right]^{[\mathrm{a}]}$} & $1.17\left({ }^{1} J_{\mathrm{PtP}}=3733 \mathrm{~Hz}\right)$ & -40 & 1.7 \\
\hline 13 & {$\left[\left(\mathrm{Et}_{3} \mathrm{P}\right) \mathrm{ClPd}(\mu-\mathrm{Cl})_{2} \mathrm{PtCl}\left(\mathrm{PEt}_{3}\right)\right]^{[8]}$} & 50.4 & 25 & 4.8 \\
\hline 14 & {$\left[\left(\mathrm{C}_{10} \mathrm{H}_{16}\right) \mathrm{ClRu}(\mu-\mathrm{Cl})_{2} \mathrm{RuCl}(\text { cymene })\right]^{[4 \mathrm{c}]}$} & - & 25 & 7.0 \\
\hline 15 & {$\left[\left(\mathrm{C}_{10} \mathrm{H}_{16}\right) \mathrm{ClRu}(\mu-\mathrm{Cl})_{2} \mathrm{RhClCp} *\right]^{[4 \mathrm{c}]}$} & - & -20 & 9.0 \\
\hline 16 & {$\left[\left(\mathrm{C}_{10} \mathrm{H}_{16}\right) \mathrm{ClRu}(\mu-\mathrm{Cl})_{2} \mathrm{IrClCp} *\right]^{\left[\mathrm{Ac}_{\mathrm{c}}\right]}$} & - & -20 & $4.0 \cdot 10^{1}$ \\
\hline 17 & {$\left[\left(\mathrm{C}_{3} \mathrm{H}_{5}\right)_{2} \mathrm{Rh}(\mu-\mathrm{Cl})_{2} \mathrm{PtCl}\left(\mathrm{PBu}_{3}\right)\right]$} & $-1.97\left({ }^{1} J_{\mathrm{PtP}}=3687 \mathrm{~Hz}\right)$ & -40 & $8.8 \cdot 10^{1}$ \\
\hline 18 & {$\left[(\mathrm{ppy})_{2} \mathrm{Rh}(\mu-\mathrm{Cl})_{2} \mathrm{PtCl}\left(\mathrm{PBu}_{3}\right)\right]^{[4 \mathrm{~b}]}$} & $-2.80\left({ }^{1} J_{\mathrm{PtP}}=3489 \mathrm{~Hz}\right)$ & 25 & $>10^{2}$ \\
\hline 19 & {$\left[(\mathrm{ppy})_{2} \mathrm{Rh}(\mu-\mathrm{Cl})_{2} \mathrm{Rh}(\mathrm{cod})\right]^{[46]}$} & - & 25 & $>10^{2}$ \\
\hline 20 & {$\left[\left(\mathrm{C}_{10} \mathrm{H}_{16}\right) \mathrm{ClRu}(\mu-\mathrm{Cl})_{2} \mathrm{PtCl}\left(\mathrm{PBu}_{3}\right)\right]^{[4 \mathrm{c}]}$} & $-0.07\left({ }^{1} J_{\mathrm{PtP}}=3770 \mathrm{~Hz}\right)$ & 25 & $>10^{2}$ \\
\hline 21 & {$\left[\left(\mathrm{C}_{3} \mathrm{H}_{5}\right) \mathrm{Pd}(\mu-\mathrm{Cl})_{2} \mathrm{Pt}\left(\mathrm{PBu}_{3}\right)_{2}\right]\left(\mathrm{BF}_{4}\right)^{[4 \mathrm{a}]}$} & $5.75\left({ }^{1} J_{\mathrm{PtP}}=3598 \mathrm{~Hz}\right)$ & 25 & $>10^{2}$ \\
\hline
\end{tabular}

${ }^{\text {[a] }} \operatorname{cod}=1,5$-cyclooctadiene. $-{ }^{[\mathrm{b}]} \mathrm{dmb}=$ ortho-metallated dimethylbenzylamine. 
not observed under similar conditions. A "cis-trans" isomerization has also been observed for heterodimeric complexes with a significantly higher equilibrium constant, such as $\left[(\text { ppy })_{2} \mathrm{Rh}(\mu-\mathrm{Cl})_{2} \mathrm{PtCl}\left(\mathrm{PBu}_{3}\right)_{2}\right]$ (Table 1, Entry 18), or for symmetrical complexes such as $\left[\left(\mathrm{Ph}_{3} \mathrm{P}\right)(\mathrm{CO}) \mathrm{Rh}(\mu-\mathrm{Cl})\right]_{2} \cdot{ }^{[11]}$ Recently, the same fluxional process was detected for mixed-valence rhodium complexes of the formula $\left[\left(\mathrm{Ph}_{3} \mathrm{P}\right)_{2} \mathrm{H}_{2} \mathrm{Rh}(\mu-\mathrm{X})_{2} \mathrm{Rh}(\mathrm{CO})\left(\mathrm{PPh}_{3}\right)\right](\mathrm{X}=\mathrm{Cl}, \mathrm{I}){ }^{[12]} \mathrm{A}$ plausible mechanism for this isomerization is a dissociative opening of one halide bridge, followed by rotation about the remaining bridge and subsequent reformation of the second one.

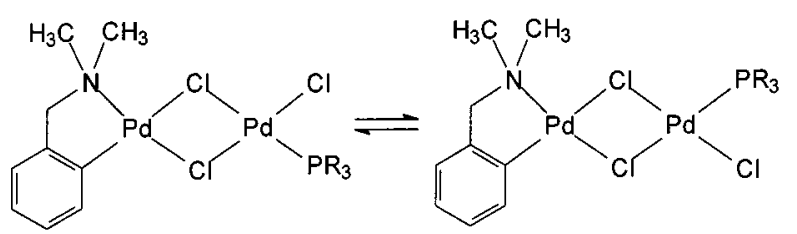

Scheme 2

Secondly, the metathesis reaction itself can be fast compared to the NMR time scale. If this is the case, a coalescence of the signals due to the symmetrical and asymmetrical complexes is observed. Such behaviour was found for $\left[\left(\mathrm{C}_{3} \mathrm{H}_{5}\right) \mathrm{Pd}(\mu-\mathrm{Cl})_{2} \mathrm{PdCl}\left(\mathrm{PEt}_{3}\right)\right]$ (Table 1, Entry 3). At $-40{ }^{\circ} \mathrm{C}$, the ${ }^{31} \mathrm{P}$ NMR spectrum shows two distinct signals due to $\left[\left(\mathrm{Et}_{3} \mathrm{P}\right) \mathrm{PdCl}(\mu-\mathrm{Cl})\right]_{2}$ and $\left[\left(\mathrm{C}_{3} \mathrm{H}_{5}\right) \mathrm{Pd}(\mu-\mathrm{Cl})_{2} \mathrm{PdCl}\left(\mathrm{PEt}_{3}\right)\right]$ in a ratio of $100: 34\left(K=1.2 \cdot 10^{-1}\right)$. At temperatures above 20 ${ }^{\circ} \mathrm{C}$, on the other hand, only one broad signal is detected (Figure 1).

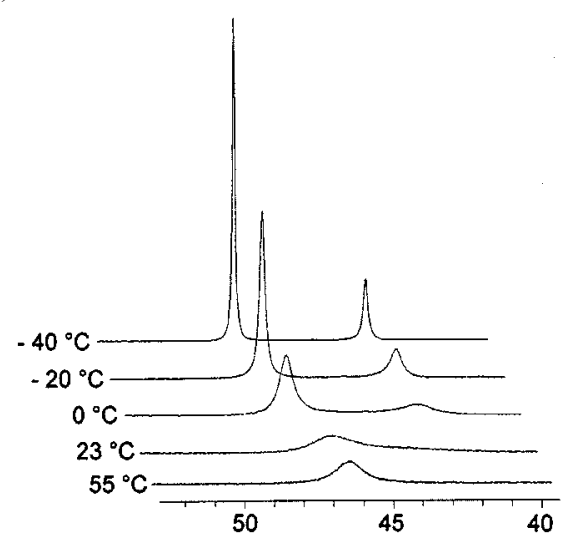

Figure 1. ${ }^{31} \mathrm{P}$ NMR spectra of $\left[\left(\mathrm{C}_{3} \mathrm{H}_{5}\right) \mathrm{Pd}(\mu-\mathrm{Cl})_{2} \mathrm{PdCl}\left(\mathrm{PEt}_{3}\right)\right]$ (in $\left.\mathrm{CDCl}_{3}\right)$ at various temperatures

From the data summarized in Table 1, some trends regarding the stabilities of the asymmetric complexes can be deduced. In all cases investigated, the metathesis reaction between two $\mathrm{d}^{8}$ complexes gave equilibrium constants close to $K=1.0$, the value expected for a statistical distribution. Complexes with $\left(\mathrm{R}_{3} \mathrm{P}\right) \mathrm{PtCl}$ fragments generally proved to be more stable than those with $\left(\mathrm{R}_{3} \mathrm{P}\right) \mathrm{PdCl}$ fragments (Table 1, Entries 3/9, 4/12, 10/17). The nature of the halo bridge is seen to have only a small effect on the position of the equilibrium with $K_{\mathrm{Cl}}>K_{\mathrm{Br}}>K_{\mathrm{I}}$ (Table 1, Entries 1-3). The highest equilibrium constants were found for complexes containing metals in different oxidation states such as $\mathrm{Ru}^{\mathrm{IV}}, \mathrm{Rh}^{\mathrm{III}}$, or $\mathrm{Ir}^{\mathrm{III}}$ in combination with metal ions in oxidation state II, or for complexes with positively charged metal fragments such as $\left[\left(\mathrm{R}_{3} \mathrm{P}\right)_{2} \mathrm{PtCl}\right]^{+}$. Other asymmetric halo-bridged complexes not synthesized by metathesis and for which an equilibrium with the corresponding homodimeric complexes has not been discussed, such as $\mathbf{3}$ $\left(\mathrm{Rh}^{\mathrm{III}}-\mathrm{Rh}^{\mathrm{I}}\right),{ }^{[5,6]} 4\left(\mathrm{Ir}^{\mathrm{III}}-\mathrm{Pd}^{\mathrm{II}}\right),{ }^{[13]} 5\left(\mathrm{Pt}^{\mathrm{IV}}-\mathrm{Pt}^{\mathrm{II}}\right),{ }^{[14]}$ and $\mathbf{6}(\mathrm{a}$ combination of formally negative and positive fragments), ${ }^{[15]}$ share the same characteristic.

\section{Computational Study}

To complement the experimental results, a computational study was carried out on five different asymmetric complexes (7-11) together with the corresponding symmetrical complexes using density functional theory at the B3LYP level with effective core potentials for the heavy metals. Complexes 7-11 were chosen because structural, vibrational, and NMR data are available for several closely related chloro compounds (in the computational model species, $\mathrm{PH}_{3}$ was used instead of $\mathrm{PR}_{3}$ ). These data were used to validate the computational results. ${ }^{[16]}$
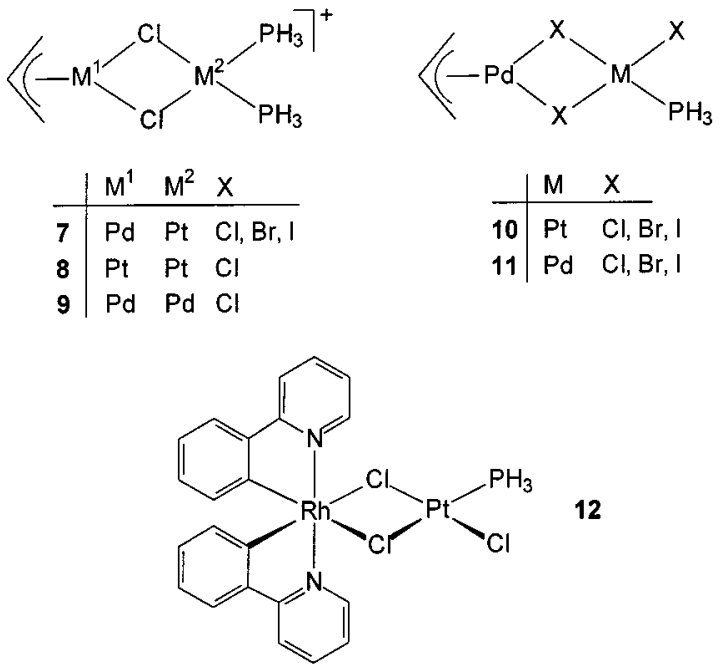

In Table 2, selected structural data for some of the computed species are compared with the experimental data. The molecular structures of all the species were fully optimized at the B3LYP level and characterized as minima by a frequency analysis. For $\left[\left(\mathrm{H}_{3} \mathrm{P}\right) \mathrm{MCl}(\mu-\mathrm{Cl})\right]_{2}(\mathrm{M}=\mathrm{Pd}, \mathrm{Pt})$, two different isomers (cis and trans) were obtained. The trans isomer was found to be stabilized by ca. $3 \mathrm{kcal} / \mathrm{mol}$ at the HF and B3LYP levels. This is in agreement with the experimental results, which show that the trans isomer is favoured both in solution as well as in the crystal. ${ }^{[27,46,48]}$ An exception is the triphenylphosphane complex $\left[\left(\mathrm{Ph}_{3} \mathrm{P}\right) \mathrm{PtCl}(\mu-\right.$ $\mathrm{Cl})]_{2}$, for which the cis form can be isolated. ${ }^{[17]}$ Two isomers were also found for the allyl complexes $\left[\left(\mathrm{C}_{3} \mathrm{H}_{5}\right) \mathrm{M}(\mu-\mathrm{Cl})\right]_{2}$ $(\mathrm{M}=\mathrm{Pd}, \mathrm{Pt})$ : a planar trans isomer with a centre of symmetry and a cis form with a bent chloro bridge ( $\mathrm{Pt}$ : $\theta=$ $157.4^{\circ}$; Pd: $\theta=167.5^{\circ}$ ). The pairs of isomers are very similar in energy $\left[\Delta E_{\mathrm{B} 3 \mathrm{LYP}}\left(\mathrm{Pt}_{\text {cis/trans }}\right)=-2.60 \mathrm{kcal} / \mathrm{mol}\right.$; $\left.\Delta E_{\mathrm{B} 3 \mathrm{LYP}}\left(\mathrm{Pd}_{\text {cis/trans }}\right)=+0.04 \mathrm{kcal} / \mathrm{mol}\right]$. This result is confirmed by the observation that both isomeric forms have been reported for substituted allylpalladium complexes. ${ }^{[18]}$ 
Table 2. Selected structural data for all computed species at the B3LYP level in comparison with experimental data

\begin{tabular}{|c|c|c|c|c|c|c|c|c|}
\hline Entry & Complex & calcd./ref. & $\begin{array}{l}\mathrm{M}-\mathrm{Cl}^{1} \\
{[\AA]}\end{array}$ & $\begin{array}{l}\mathrm{M}-\mathrm{Cl}^{2} \\
{[\mathrm{~A}]}\end{array}$ & $\begin{array}{l}\mathrm{M}^{1}-\mathrm{M}^{2} \\
{[\mathrm{~A}]}\end{array}$ & $\begin{array}{l}\mathrm{Cl}^{1}-\mathrm{M}^{1}-\mathrm{Cl}^{2} \\
\left.{ }^{\circ}\right]\end{array}$ & $\begin{array}{l}\mathrm{Cl}^{1}-\mathrm{M}^{2}-\mathrm{Cl}^{2} \\
\left.{ }^{\circ}\right]\end{array}$ & $\begin{array}{l}\theta \\
{\left[{ }^{\circ}\right]}\end{array}$ \\
\hline 1 & {$\left[\left(\mathrm{C}_{3} \mathrm{H}_{5}\right) \operatorname{Pt}(\mu-\mathrm{Cl})\right]_{2}{ }^{[\mathrm{a}]}$} & calcd. & 2.47 & 2.47 & 3.68 & 83.5 & 83.5 & 180.0 \\
\hline 2 & {$\left[\left(\mathrm{C}_{3} \mathrm{H}_{5}\right) \mathrm{Pd}(\mu-\mathrm{Cl})\right]_{2}{ }^{[\mathrm{a}]}$} & calcd. & 2.45 & 2.45 & 3.52 & 88.2 & 88.2 & 180.0 \\
\hline 3 & {$\left[\left(\mathrm{C}_{3} \mathrm{H}_{5}\right) \mathrm{Pd}(\mu-\mathrm{Cl})\right]_{2}$} & ref. ${ }^{[44]}$ & 2.41 & 2.41 & 3.48 & 88.3 & 88.3 & 180.0 \\
\hline 4 & {$\left[\left(\mathrm{H}_{3} \mathrm{P}\right)_{2} \mathrm{Pt}(\mu-\mathrm{Cl})\right]_{2}{ }^{2+}$} & calcd. & 2.46 & 2.46 & 3.65 & 84.1 & 84.1 & 180.0 \\
\hline 5 & {$\left[(\mathrm{dppb})_{2} \mathrm{Pt}(\mu-\mathrm{Cl})\right]_{2}^{2+[\mathrm{b}]}$} & ref. $^{[45]}$ & 2.41 & 2.41 & 3.75 & 77.3 & 77.3 & 180.0 \\
\hline 6 & trans $-\left[\left(\mathrm{H}_{3} \mathrm{P}\right) \mathrm{PtCl}(\mu-\mathrm{Cl})\right]_{2}$ & calcd. & $2.46^{[\mathrm{c}]}$ & $2.41^{[\mathrm{d}]}$ & 3.60 & 84.7 & 84.7 & 180.0 \\
\hline 7 & trans $-\left[\left(\mathrm{Et}_{3} \mathrm{P}\right) \mathrm{PtCl}(\mu-\mathrm{Cl})\right]_{2}$ & $\operatorname{ref}^{[46]}$ & $2.43^{[\mathrm{c}]}$ & $2.32^{[\mathrm{d}]}$ & 3.54 & 83.5 & 83.5 & 180.0 \\
\hline 8 & {$\left[\left(\mathrm{H}_{3} \mathrm{P}\right)_{2} \mathrm{Pd}(\mu-\mathrm{Cl})\right]_{2}^{2+}$} & calcd. & 2.43 & 2.43 & 3.55 & 86.2 & 86.2 & 180.0 \\
\hline 9 & {$\left[\left(\mathrm{Ph}_{3} \mathrm{P}\right)_{2} \mathrm{Pd}(\mu-\mathrm{Cl})\right]_{2}^{2+}$} & ref. $^{[47]}$ & 2.39 & 2.35 & 3.50 & 84.9 & 84.9 & 176.2 \\
\hline 10 & trans $-\left[\left(\mathrm{H}_{3} \mathrm{P}\right) \mathrm{PdCl}(\mu-\mathrm{Cl})\right]_{2}$ & calcd. & $2.44^{[c]}$ & $2.39^{[\mathrm{d}]}$ & 3.52 & 86.5 & 86.5 & 180.0 \\
\hline 11 & trans $-\left[\left(\mathrm{Bu}_{3} \mathrm{P}\right) \mathrm{PdCl}(\mu-\mathrm{Cl})\right]_{2}$ & ref. $^{[48]}$ & $2.44^{[\mathrm{c}]}$ & $2.31^{[\mathrm{d}]}$ & 3.48 & 85.7 & 85.7 & 180.0 \\
\hline 12 & {$\left[\left(\mathrm{C}_{3} \mathrm{H}_{5}\right) \mathrm{Pd}(\mu-\mathrm{Cl})_{2} \mathrm{Pt}\left(\mathrm{PH}_{3}\right)_{2}\right]^{+}$} & calcd. & $2.52^{[\mathrm{e}]}$ & $2.41^{[\mathrm{f}]}$ & 3.59 & $83.0^{[\mathrm{e}]}$ & $87.4^{[\mathrm{f}]}$ & 164.3 \\
\hline 13 & {$\left[\left(\mathrm{C}_{3} \mathrm{H}_{5}\right) \mathrm{Pd}(\mu-\mathrm{Cl})_{2} \mathrm{Pt}\left(\mathrm{PBu}_{3}\right)_{2}\right]^{+}$} & ref. ${ }^{[4 a]}$ & $2.40^{[\mathrm{e}]}$ & $2.40^{[\mathrm{f}]}$ & 3.57 & $83.0^{[\mathrm{e}]}$ & $83.0^{[\mathrm{f}]}$ & 167.9 \\
\hline 14 & {$\left[\left(\mathrm{C}_{3} \mathrm{H}_{5}\right) \mathrm{Pt}(\mu-\mathrm{Cl})_{2} \mathrm{Pt}\left(\mathrm{PH}_{3}\right)_{2}\right]^{+} \mathbf{( 8 )}$} & calcd. & $2.53^{[\mathrm{e}]}$ & $2.47^{[\mathrm{f}]}$ & 3.59 & $80.7^{[\mathrm{e}]}$ & $85.5^{[\mathrm{f}]}$ & 152.4 \\
\hline 15 & {$\left[\left(\mathrm{C}_{3} \mathrm{H}_{5}\right) \mathrm{Pd}(\mu-\mathrm{Cl})_{2} \mathrm{Pd}\left(\mathrm{PH}_{3}\right)_{2}\right]^{+}(\mathbf{9})$} & calcd. & $2.51^{[\mathrm{e}]}$ & $2.38^{[\mathrm{f}]}$ & 3.54 & $83.7^{[\mathrm{e}]}$ & $89.4^{[\mathrm{f}]}$ & 164.7 \\
\hline 16 & {$\left[\left(\mathrm{C}_{3} \mathrm{H}_{5}\right) \mathrm{Pd}(\mu-\mathrm{Cl})_{2} \mathrm{PtCl}\left(\mathrm{PH}_{3}\right)\right](\mathbf{1 0})$} & calcd. & $2.47^{[\mathrm{e}]}$ & $2.41^{[\mathrm{f}]}$ & 3.56 & $85.3^{[\mathrm{e}]}$ & $86.6^{[\mathrm{f}]}$ & 171.4 \\
\hline 17 & {$\left[\left(\mathrm{C}_{3} \mathrm{H}_{5}\right) \mathrm{Pd}(\mu-\mathrm{Cl})_{2} \mathrm{PdCl}\left(\mathrm{PH}_{3}\right)\right]$} & calcd. & $2.47^{[\mathrm{e}]}$ & $2.40^{[\mathrm{f}]}$ & 3.52 & $86.0^{[\mathrm{e}]}$ & $88.1^{[\mathrm{f}]}$ & 174.3 \\
\hline
\end{tabular}

[a] $\left(\mathrm{C}_{3} \mathrm{H}_{5}\right)$ trans to $\left(\mathrm{C}_{3} \mathrm{H}_{5}\right) .-{ }^{[\mathrm{b}]} \mathrm{dppb}=1$,4-bis(diphenylphosphanyl)butane. $-{ }^{[\mathrm{c}]} \mathrm{Cl}$ trans to $\mathrm{PR}_{3} .-{ }^{[\mathrm{d}]} \mathrm{Cl}$ trans to $\mathrm{Cl}$. $-{ }^{[\mathrm{e}]} \mathrm{M}=\mathrm{M}\left(\mathrm{C}_{3} \mathrm{H}_{5}\right.$. $-{ }^{[\mathrm{f}]} \mathrm{M}=\mathrm{M}\left(\mathrm{PR}_{3}\right)$.

A more complicated situation is encountered with the rhodium complex $\left[(\mathrm{ppy})_{2} \mathrm{Rh}(\mu-\mathrm{Cl})\right]_{2}(\mathbf{1 2})$. Not only the size of the ligands (as a consequence of which only the HF method was utilized) but also different isomers of the complexes need to be considered. Since the rhodium atoms are stereogenic centres, diastereoisomers are observed: the homochiral complexes $\Delta \Delta$ and $\Lambda \Lambda$, as well as the meso complex $\Delta \Lambda$. The homochiral complexes are energetically favoured by $7.77 \mathrm{kcal} / \mathrm{mol}$ at Hartree-Fock level. On the basis of molecular modelling studies of $\left[(p p y){ }_{2} \mathrm{Rh}(\mu-\mathrm{Cl})\right]_{2}{ }^{[19]}$ and closely related complexes, ${ }^{[20]}$ it has previously been suggested that the meso form is less stable due to interligand steric repulsion. Accordingly, for this class of compounds only $\Delta \Delta / \Lambda \Lambda$ complexes have been structurally characterized. ${ }^{[20,21]}$

A common feature of all the symmetrical complexes is a planar $\mathrm{M}(\mu-\mathrm{Cl})_{2} \mathrm{M}$ unit (Table 2, Entries 1-11), the only exception being $\left[\left(\mathrm{PPh}_{3}\right)_{2} \mathrm{Pd}(\mu-\mathrm{Cl})\right]_{2}{ }^{2+}$, which displays a slightly bent chloro bridge in the crystal. This characteristic is also observed for most other halo-bridged complexes of $\mathrm{d}^{8}$ transition metal ions. ${ }^{[22]}$ For all asymmetric complexes, on the other hand, a bent chloro bridge $\left(\theta=152-174^{\circ}\right)$ and two significantly different $\mathrm{Cl}^{1} \mathrm{M}^{1}$ and $\mathrm{Cl}^{1} \mathrm{M}^{2}$ bond lengths are found (Table 2, Entries 12-17). This striking property is in agreement with the experimental results; e.g. a bent chloro bridge $\left(\theta=164^{\circ}\right)$ was found for the optimized structure of 7 and an angle of $168^{\circ}$ was observed for $\left[\left(\mathrm{C}_{3} \mathrm{H}_{5}\right) \mathrm{Pd}(\mu-\mathrm{Cl})_{2} \mathrm{Pt}\left(\mathrm{PBu}_{3}\right)_{2}\right]\left(\mathrm{BF}_{4}\right)$ in the crystal. To determine the energy difference between the planar and bent forms, the bending potentials of 7 in the range $230^{\circ}$ to $130^{\circ}$ were investigated. Apparently, the potential is very flat $\left[\Delta E\left(180^{\circ}-164^{\circ}\right) \approx 0.1 \mathrm{kcal} / \mathrm{mol}\right]$ and, as expected, is not symmetrical (Figure 2). The bent chloro bridges observed for asymmetric complexes are thus a direct consequence of the reduced symmetry of these compounds. Moreover, the very flat bending potential indicates that Coulomb and packing forces may be of great relevance to the structure upon crystallization.
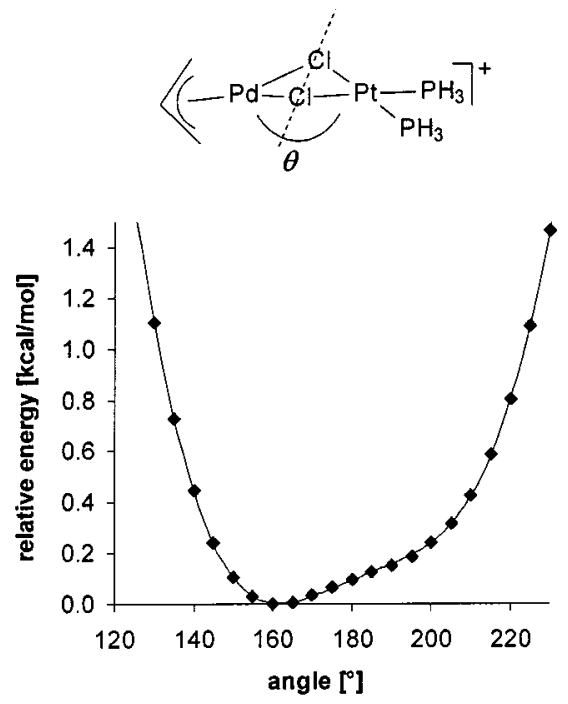

Figure 2. Relative energy of $\left[\left(\mathrm{C}_{3} \mathrm{H}_{5}\right) \mathrm{Pd}(\mu-\mathrm{Cl})_{2} \mathrm{Pt}\left(\mathrm{PH}_{3}\right)_{2}\right]^{+}$as a function of the bending angle $\theta$

Overall, the calculated structural parameters are in good agreement with the experimental data. It should be noted that the computation was carried out for single, isolated (gas-phase) molecules with $\mathrm{PH}_{3}$ ligands instead of bulky $\mathrm{PR}_{3}$ ligands. Therefore, small differences between the gasphase and solid-state data are to be expected.

In a second step of our investigation, the thermodynamics of the equilibrium reactions (Scheme 1) of the asymmetric complexes 7-11 was studied. The total energies and zero-point vibrational energies, the molecular free enthalpies, and the equilibrium constants of all the reactions are summarized in Table 3. From these data, and in excellent agreement with the experimental findings, it can be stated that in the case of equilibrium reactions with the mono- 
cationic phosphane complexes 7-9, only the metathesis products should be observed. These reactions are fairly exothermic $(-65$ to $-75 \mathrm{kcal} / \mathrm{mol})$ and therefore have very large equilibrium constants associated with them. Apparently, the nature of the metal ion (Pd or Pt) has only a very small influence on the energetics. Thus, formation of the homodimeric Pt complex $\mathbf{8}$ is only slightly more exothermic than that of the corresponding Pd complex 9. The situation changes dramatically when neutral $\mathrm{d}^{8}$ complexes undergo the same reaction (10 and 11). Here, the free enthalpy of the metathesis lies on the borderline between exothermic and endothermic reactions. Therefore, the formation of the asymmetric complexes (regardless of whether they are homo- or heterodinuclear) represents an observable equilibrium with a very small equilibrium constant (compared to the formation of 7-9). Again, this fact represents a nice agreement between experiment and theory. Furthermore, we looked at the influence of the bridging halo ligand. Like the effect of the metal centre, changing the halogen was found to have only a small influence on the thermodynamic stabilities of the asymmetric complexes, the equilibrium
7-9 and 0.06 to 0.10 e for the neutral complexes $\mathbf{1 0}$ and $\mathbf{1 1}$. It is interesting to note that a considerable proportion of the values for 7-9 stems from the allyl ligand and is mainly "received" by the $\mathrm{PH}_{3}$ ligand, e.g. for $70.162 \mathrm{e}$ is donated by the allyl ligand and $0.150 \mathrm{e}$ is accepted by the two $\mathrm{PH}_{3}$ ligands $\left(0.075 \mathrm{e}\right.$ per $\left.\mathrm{PH}_{3}\right)$ with a total electron transfer of $0.203 \mathrm{e}$ between the two different monomers. As the allyl ligand acts as a donor and therefore possesses a much smaller negative charge in the metathesis product, a dramatic change in the chemical reaction behaviour towards nucleophilic attack on the allyl group is to be expected. This is especially interesting since allylpalladium complexes are versatile catalysts for allylic substitutions. ${ }^{[23]}$

Investigation of the reaction of $\left[(\mathrm{ppy})_{2} \mathrm{Rh}(\mu-\mathrm{Cl})\right]_{2}$ with $\left[\left(\mathrm{PH}_{3}\right)(\mathrm{Cl}) \mathrm{Pt}(\mu-\mathrm{Cl})\right]_{2}$ leading to $\mathbf{1 2}$ supports the hypothesis that charge transfer within the complex upon metathesis plays an important role with regard to the thermodynamic stability of such metathesis complexes. For this reaction, a large charge transfer was found (0.268e), even though only neutral complexes are involved. ${ }^{[24]}$ The phenylpyridine ligand system constitutes a very good electron donor, but the

Table 3. Total energies $\left(E_{\text {tot }} /\right.$ a.u. $)$, zero-point vibrational energies (zpe/kcal mol $\left.{ }^{-1}\right)$, enthalpies $\left(\Delta H_{298} / \mathrm{kcal} \mathrm{mol}^{-1}\right)$, free enthalpies $\left(\Delta G_{298} /\right.$ $\left.\mathrm{kcal} \mathrm{mol}^{-1}\right)$, equilibrium constants $(K)$, and charge transfer $\left(\Delta q_{\mathrm{ct}} / \mathrm{e}\right.$; negative sign means acceptor, positive sign means donor)

\begin{tabular}{lllllllllllll}
\hline & $\mathrm{X}$ & \multicolumn{1}{c}{$\Delta E_{0}$} & $\Delta H_{298}$ & $\Delta G_{298}$ & $K$ & $\Delta q \mathrm{M}\left(\mathrm{PH}_{3}\right)$ & $\Delta q \mathrm{M}_{\left(\mathrm{C}_{3} \mathrm{H}_{5}\right)}$ & $\Delta q\left(\mathrm{Cl}_{\mathrm{b}}\right)^{[\mathrm{a}] \mathrm{b}]}$ & $\Delta q\left(\mathrm{C}_{3} \mathrm{H}_{5}\right)$ & $\Delta q\left(\mathrm{PH}_{3}\right)$ & $\Delta q\left(\mathrm{Cl}_{\mathrm{t}}\right)^{[\mathrm{a}]}$ & $\Delta q_{\mathrm{ct}}{ }^{[\mathrm{c}]}$ \\
\hline $\mathbf{7}$ & $\mathrm{Cl}$ & -74.64 & -74.31 & -72.78 & $2 \cdot 10^{53}$ & -0.0052 & -0.0532 & +0.0938 & +0.1625 & -0.0752 & - & +0.2031 \\
$\mathbf{7}$ & $\mathrm{Br}$ & -74.33 & -73.37 & -74.36 & $3 \cdot 10^{54}$ & - & - & - & - & - & - \\
$\mathbf{7}$ & $\mathrm{I}$ & -72.81 & -71.88 & -73.45 & $6 \cdot 10^{53}$ & - & - & - & - & - \\
$\mathbf{8}$ & $\mathrm{Cl}$ & -72.17 & -71.82 & -71.62 & $3 \cdot 10^{52}$ & -0.0098 & -0.03614 & +0.0557 & +0.1436 & -0.0710 & - & +0.1631 \\
$\mathbf{9}$ & $\mathrm{Cl}$ & -68.86 & -68.50 & -66.56 & $6 \cdot 10^{48}$ & -0.0090 & -0.0576 & +0.0707 & +0.1619 & -0.0695 & - \\
$\mathbf{1 0}$ & $\mathrm{Cl}$ & -1.03 & -1.00 & -1.99 & 29 & +0.0106 & -0.0168 & +0.0808 & +0.0403 & -0.0342 & -0.0058 & +0.1750 \\
$\mathbf{1 0}$ & $\mathrm{Br}$ & -0.69 & -0.10 & -3.06 & 173 & - & - & - & - & - & - \\
$\mathbf{1 0}$ & $\mathrm{I}$ & 0.09 & 0.66 & -2.97 & 148 & - & - & - & - & - & - \\
$\mathbf{1 1}$ & $\mathrm{Cl}$ & -0.10 & -0.09 & -0.90 & 5 & +0.0132 & -0.0061 & +0.0491 & +0.0175 & -0.0224 & -0.0060 & +0.0605 \\
$\mathbf{1 1}$ & $\mathrm{Br}$ & -0.12 & -0.13 & 0.21 & 1 & - & - & - & - & - & - & - \\
$\mathbf{1 1}$ & $\mathrm{I}$ & 0.25 & 0.82 & -2.86 & 124 & - & - & - & - & - & - & - \\
\hline
\end{tabular}

[a] $\mathrm{b}=$ bridging, $\mathrm{t}=$ terminal. $-{ }^{[\mathrm{b}]} \Delta q\left(\mathrm{Cl}_{\mathrm{b}}\right)=\left[q_{1}\left(\mathrm{Cl}_{\mathrm{b}}, \text { product }\right)+q_{2}\left(\mathrm{Cl}_{\mathrm{b}} \text {, product }\right)\right]^{*} 0.5-q\left(\mathrm{Cl}_{\mathrm{b}}\right.$, starting material $) .-[\mathrm{c}] \Delta q_{c t}=\left[\Delta q\left(\mathrm{C}_{3} \mathrm{H}_{5}\right)\right.$ $\left.+\Delta q \mathrm{M}\left(\mathrm{C}_{3} \mathrm{H}_{5}\right)+\Delta q\left(\mathrm{Cl}_{\mathrm{b}}\right)\right]=\Delta q_{c t}($ fragment 1$)=-\Delta q_{c t}($ fragment 2$)$

constants increasing in the order $K_{\mathrm{Cl}}<K_{\mathrm{Br}} \approx K_{\mathrm{I}}$ (Table 3).

The entropy terms of all the considered metathesis reactions are fairly small (Table 3). Consequently, the temperature is found not to have any great influence on the equilibrium. This finding is in agreement with our NMR studies.

Finally, the metathesis reaction of $\left[(\mathrm{ppy})_{2} \mathrm{Rh}(\mu-\mathrm{Cl})\right]_{2}$ with $\left[\left(\mathrm{PH}_{3}\right)(\mathrm{Cl}) \mathrm{Pt}(\mu-\mathrm{Cl})\right]_{2}$ was investigated. Although this reaction results in a neutral product complex, it is essentially quantitative (Table 1, Entry 18). At HF level, we were able to confirm this experimental observation. For the homochiral rhodium complex an equilibrium constant of ca. $10^{29}$ $(\Delta E=-39.9 \mathrm{kcal} / \mathrm{mol})$ was estimated, while that for the meso complex was estimated to be ca. $10^{23}(\Delta E=-32.1$ $\mathrm{kcal} / \mathrm{mol})$.

In order to investigate the electronic situation in the asymmetric complexes 7-11, we calculated the partial charges ${ }^{[16]}$ as well as the charge transfer that occurs upon metathesis (Table 3 ). The total amount of charge transfer, $q_{\mathrm{ct}}$, lies in the range 0.20 to $0.17 \mathrm{e}$ for the cationic complexes
$\mathrm{PH}_{3}$ group does not act as the main electron acceptor $(0.061 \mathrm{e})$. Most of the redistributed charge density is transferred to the chloro bridge $(0.103 \mathrm{e})$ and to the central platinum atom $(0.074 \mathrm{e})$.

Overall, a correlation between $q_{\mathrm{ct}}$ and the exothermicity of the metathesis reaction is evident for the reactions investigated. The often discussed linear relationship between $\Delta G$ and $q_{\mathrm{ct}}$ for Lewis acid-Lewis base complexes arises from a model in which charge transfer is only allowed between donor and acceptor centres and the effects of charge redistribution and changes in structure are ignored. ${ }^{[25]}$ This may account for the observed differences.

\section{Conclusions}

The NMR data presented in this paper indicate that in organic solvents such as chloroform, halo-bridged complexes of the late transition metals generally undergo metathesis reactions to form asymmetric homo- or heterobimet- 
allic complexes. This hypothesis is wholly consistent with previously published results relating to this class of compounds. ${ }^{[26]}$ The possibility that asymmetric halo-bridged complexes are in dynamic equilibrium with the corresponding symmetric complexes should therefore be considered even if the relevant compounds have not been prepared by metathesis reactions (e.g. 1, 2, and 4-6). Due to the high lability of the halo bridge, the metathesis reaction is very fast, in some cases even fast compared to the NMR time scale. The position of the equilibrium strongly depends on the nature of the participating metal fragments. For combinations of two neutral $\mathrm{d}^{8}$ complexes, only small equilibrium constants close to the statistical value of $K=1.0$ have been observed. For charged metal fragments or complexes in different oxidation states, however, the equilibrium may lie completely on the side of the asymmetric complex.

These findings have been confirmed by the results of theoretical investigations. Interestingly, the difference between the metathesis reactions of neutral complexes vs. cationic complexes or complexes with different oxidation states is to some extent correlated with the charge redistribution that occurs upon metathesis. The charge transfer has consequences regarding the reactivities of compounds of this class, which are expected to differ from those of the corresponding symmetrical complexes. We are currently investigating possible applications of asymmetric halo-bridged complexes in homogeneous catalysis and the first results will be reported in due course.

\section{Experimental Section}

General Remarks: NMR spectra were recorded with JEOL EX 400 or GSX 270 spectrometers taking the solvent signal as an internal standard. The complexes $\left[\left(\mathrm{PR}_{3}\right) \mathrm{MX}(\mu-\mathrm{X})\right]_{2}(\mathrm{M}=\mathrm{Pd}, \mathrm{Pt} ; \mathrm{R}=\mathrm{Et}$, $\mathrm{Bu} ; \mathrm{X}=\mathrm{Cl}, \mathrm{Br}, \mathrm{I}),{ }^{[27]}[(\operatorname{cod}) \mathrm{Rh}(\mu-\mathrm{Cl})]_{2},{ }^{[28]}[(\operatorname{cod}) \operatorname{Ir}(\mu-\mathrm{Cl})]_{2},{ }^{[29]}\left[\mathrm{Cp}^{*}\right.$ $\operatorname{MCl}(\mu-\mathrm{Cl})]_{2} \quad(\mathrm{M}=\mathrm{Rh}, \quad \mathrm{Ir}),{ }^{\left[{ }^{[30]}\right.}[(\text { cymene }) \operatorname{RuCl}(\mu-\mathrm{Cl})]_{2},{ }^{[31]}$ $\left[\left(\mathrm{C}_{3} \mathrm{H}_{5}\right)_{2} \mathrm{Rh}(\mu-\mathrm{Cl})_{2}\right]_{2},{ }^{[32]}[(\mathrm{dmb}) \mathrm{Pd}(\mu-\mathrm{Cl})]_{2},{ }^{[33]}$ and $\left[\left(\mathrm{C}_{3} \mathrm{H}_{5}\right) \mathrm{Pd}(\mu-\right.$ $\left.\mathrm{Cl}_{2}\right]_{2}{ }^{[34]}$ were prepared according to literature procedures.

NMR Experiments: $\mathrm{CDCl}_{3}$ or $\mathrm{CD}_{2} \mathrm{Cl}_{2}(600 \mu \mathrm{L})$ was added to equimolar amounts ( $30 \mu \mathrm{mol}$ each) of two different halo-bridged complexes. Once the compounds had dissolved, the solution was transferred to an NMR tube. Spectra were recorded at $-40^{\circ} \mathrm{C}$, except where otherwise indicated.

Computational Details: The structural and vibrational data of the species under consideration were calculated by means of density functional theory using the program package Gaussian $98 .{ }^{[35]}$ For $\mathrm{Br}$ and I (I: ECP46MWB; Br: ECP28MWB) ${ }^{[36]}$ as well as for $\mathrm{Pt}$ and Pd (Pd: ECP28MWB; Pt: ECP60MWB), ${ }^{[37]}$ quasi-relativistic pseudopotentials of the Stuttgart group ${ }^{[38]}$ were utilized. The use of this pseudopotential facilitates the treatment of major relativistic effects such as Darwin and mass velocity terms. Spin-orbit interaction is not included. For $\mathrm{H}, \mathrm{C}, \mathrm{P}$, and $\mathrm{Cl}$, a standard 6-31G(d,p) basis set was used, for $\mathrm{Br}$ and $\mathrm{I}$ a $(5 \mathrm{~s} 5 \mathrm{p} 1 \mathrm{~d}) /[3 \mathrm{~s} 3 \mathrm{p} 1 \mathrm{~d}] \mathrm{DZ}+\mathrm{P}$ basis set, ${ }^{[39]}$ and for Pt and Pd an $(8 \mathrm{~s} 7 \mathrm{p} 6 \mathrm{~d}) /[6 \mathrm{~s} 5 \mathrm{p} 3 \mathrm{~d}]$ basis set. ${ }^{[36]}-$ The computations were carried out at the HF level (pre-optimization) and at the DFT level using the hybrid method B3LYP, which includes a mixture of Hartree-Fock exchange with DFT exchange correlation. Becke's 3-parameter functional, where the non-local correlation is provided by the LYP expression (Lee, Yang, Parr correlation functional), was used as implemented in Gaussian 98. For a concise definition of the B3LYP functional, see ref. ${ }^{[40]}-$ The theoretically predicted vibrational frequencies ${ }^{[16]}$ for all the species were calculated with the harmonic approximation. It was found that the deviation from the experimentally obtained frequencies could be partly be compensated by using scaling factors. The frequencies may also be different for various vibrational modes accessible to the molecules. ${ }^{[41]}$ - The metathesis energies were corrected for zero-point vibrational energies obtained at the same level of theory from unscaled harmonic vibrational frequencies. Thermal corrections were also made to allow estimation of the molecular free enthalpies of metathesis and equilibrium constants. Atomic charges (NPA) and the extent of charge transfer were determined by means of NBO analysis. ${ }^{[42,43]}$ It should be emphasized that the computation was carried out for a single, isolated (gas-phase) molecule. There may well be significant differences between gas-phase and solid-state data. In addition, to save CPU time $\mathrm{PH}_{3}$ was used instead of $\mathrm{PPh}_{3}$ in our model species.

\section{Acknowledgments}

K. S. and A. S. thank Prof. Dr. W. Beck (LMU München) and Prof. Dr. T. M. Klapötke (LMU München) for their generous support and E. Karaghiosoff for technical assistance. Financial funding from the Bayerischer Habilitations-Förderpreis (K. S.) is gratefully acknowledged. We also wish to thank the Leibniz Rechenzentrum (München) for a generous allocation of CPU time.

[1] [1a] Comprehensive Organometallic Chemistry (Eds.: G. Wilkinson, F. G. A. Stone), vols. 4-6 and 8, Pergamon Press, Oxford, 1982. - ${ }^{[1 \mathrm{~b}]}$ Comprehensive Organometallic Chemistry II (Eds.: E. W. Abel, F. G. A. Stone, G. Wilkinson), vols. 7-9 and 12, Pergamon Press, Oxford, 1995.

[2] E. L. Dias, R. H. Grubbs, Organometallics 1998, 17, 2758. Structurally related allenylidene complexes have been described: A. Fürstner, A. F. Hill, M. Liebl, J. D. E. T. WiltonEly, Chem. Commun. 1999, 601.

[3] T. Weslamp, F. J. Kohl, W. Hieringer, D. Gleich, W. Herrmann, Angew. Chem. 1999, 111, 2573-2576; Angew. Chem. Int. Ed. 1999, 38,2416

${ }^{[4]}{ }^{[4 a]}$ K. Polborn, K. Severin, J. Chem. Soc., Dalton Trans. 1999, 759. $-{ }^{[4 \mathrm{~b}]}$ K. Polborn, K. Severin, Eur. J. Inorg. Chem. 1998, 1187. $-{ }^{[4 c]}$ K. Severin, S. Mihan, W. Beck, Inorg. Chim. Acta $1995,240,339$.

[5] [5a] M. I. Bruce, B. L. Goodall, M. Z. Iqbal, F. G. A. Stone, J. Chem. Soc., Chem. Commun. 1971, 661. - ${ }^{[5 \mathrm{~b}]}$ A. R. M. Craik, G. R. Knox, P. L. Pauson, R. J. Hoare, O. S. Mills, J. Chem. Soc., Chem. Commun. 1971, 168. - ${ }^{[5 c]}$ M. I. Bruce, M. Z. Iqbal, F. G. A. Stone, J. Organomet. Chem. 1972, 40, 393.

${ }^{[6]}$ R. J. Hoare, O. S. Mills, J. Chem. Soc., Dalton Trans. 1972, 2141 .

[7] [7a] C. Masters, J. P. Visser, J. Chem. Soc., Chem. Commun. 1974, $932 .-{ }^{[76]}$ A. A. Kiffen, C. Masters, J. P. Visser, J. Chem. Soc., Dalton Trans. 1975, 1311

[8] H. C. Clark, G. Ferguson, V. K. Jain, M. Parvez, Inorg. Chem. 1985, 24, 1477.

[9] Asymmetric complexes have been detected for other combinations but due to poor separation of the corresponding NMR signals an accurate determination of the equilibrium constant was not possible.

${ }^{[10]} \mathrm{H}$. Friebolin, Ein- und zweidimensionale NMR-Spektroskopie, VCH, Weinheim, 1992, p. 285.

[11] G. Giordano, E. Rotondo, Polyhedron 1994, 13, 2507.

${ }^{[12]}$ P. D. Morran, S. B. Duckett, P. R. Howe, J. E. McGrady, S. A. Colebrooke, R. Eisenberg, M. G. Partridge, J. A. B. Lohman, J. Chem. Soc., Dalton Trans. 1999, 3949.

${ }^{[13]}$ C. E. Briant, K. A. Rowland, C. T. Webber, D. M. P. Mingos, J. Chem. Soc., Dalton Trans. 1981, 1515. 
${ }^{[14]}$ E. J. Parsons, R. D. Larsen, P. W. Jennings, J. Am. Chem. Soc. 1985, 107, 1793.

[15] 15a G. López, G. García, G. Sánchez, C. de Haro, M. D. Santana, J. Casabó, M. Caldés, M. Mejías, E. Molins, C. Miravitlles, J. Chem. Soc., Dalton Trans. 1991, 3311. - 15b G. López, G. García, C. de Haro, G. Sánchez, J. García, J. Organomet. Chem. 1986, 317, C23.

${ }^{[16]}$ Supplementary data are available on request (total energies, frequencies, NBO partial charges, HF data).

[17] 17a N. M. Boag, M. S. Ravetz, J. Chem. Soc., Dalton Trans. 1995, 3473. - 17b F. R. Hartley, G. W. Searle, Inorg. Chem. 1973, 12, 1949.

${ }^{[18]}$ J.-M. Rosset, M. P. Glenn, J. D. Cotton, A. C. Willis, C. H. L. Kennard, K. A. Byriel, B. H. Riches, W. Kitching, Organometallics 1998, 17, 1968

${ }^{[19]}$ S. Sprouse, K. A. King, P. J. Spellane, R. J. Watts, J. Am. Chem. Soc. 1984, 106, 6647.

${ }^{[20]}$ L. Ghizdavu, B. Kolp, A. v. Zelewsky, H. Stoeckli-Evans, Eur. J. Inorg. Chem. 1999, 1271.

[21] 21a P. J. Steel, J. Organomet. Chem. 1991, 408, 395. - 21 b F. O. Garces, K. Dedeian, N. L. Keder, R. J. Watts, Acta Cryst. 1993, C49, 1117.

${ }^{[22]}$ G. Aullón, G. Ujaque, A. Lledós, S. Alvarez, P. Alemany, Inorg. Chem. 1998, 37, 804 .

[23] A. Heumann, in: Transition Metals for Organic Synthesis, vol. 1 (Eds.: M. Beller, C. Bolm), Wiley-VCH, Weinheim, 1998, p. 251.

[24] Only the HF density was used here.

[25] 25a A. Y. Timoshkin, A. V. Suvorov, H. F. Bettinger, H. F. Schaefer III, J. Am. Chem. Soc. 1999, 121, 5687. - 25b V. Jonas, G. Frenking, M. T. Reetz, J. Am. Chem. Soc. 1994, 116, 8741. - ${ }^{[25 \mathrm{c}]}$ E. N. Gurjanova, I. P. Goldstein, I. P. Romm, Donor-Acceptor Bond, Wiley, New York, 1975.

[26] Only in some rare cases have side reactions such as ligand transfer been observed; see ref. ${ }^{[4 a]}$

[27] 27a W. Baratta, P. S. Pregosin, Inorg. Chim. Acta 1993, 209, 85. - 27b F. R. Hartley, Organomet. Chem. Rev. A 1970, 6, 119.

${ }^{[28]}$ G. Giordano, R. H. Crabtree, Inorg. Synth. 1990, $28,88$.

[29] J. L. Herde, J. C. Lambert, C. V. Senoff, Inorg. Synth. 1974, $15,18$.

[30] J. W. Kang, K. Moseley, P. M. Maitlis, J. Am. Chem. Soc. 1969 , 91, 5970.

${ }^{[31]}$ M. A. Bennett, T.-N. Huang, T. W. Matheson, A. K. Smith, Inorg. Synth. 1982, 21, 74.

${ }^{[32]}$ J. Powell, B. L. Shaw, J. Chem. Soc. A 1968, 583.

${ }^{[33]}$ A. C. Cope, E. C. Friedrich, J. Am. Chem. Soc. 1968, 90, 909.

${ }^{[34]}$ M. Sakakibara, Y. Takahashi, S. Sakai, Y. Ishii, J. Chem. Soc., Chem. Commun. 1969, 396-397.

${ }^{[35]}$ M. J. Frisch, G. W. Trucks, H. B. Schlegel, G. E. Scuseria, M.
A. Robb, J. R. Cheeseman, V. G. Zakrzewski, J. A. Montgomery, Jr., R. E. Stratmann, J. C. Burant, S. Dapprich, J. M. Millam, A. D. Daniels, K. N. Kudin, M. C. Strain, O. Farkas, J. Tomasi, V. Barone, M. Cossi, R. Cammi, B. Mennucci, C. Pomelli, C. Adamo, S. Clifford, J. Ochterski, G. A. Petersson, P. Y. Ayala, Q. Cui, K. Morokuma, D. K. Malick, A. D. Rabuck, K. Raghavachari, J. B. Foresman, J. Cioslowski, J. V. Ortiz, B. B. Stefanov, G. Liu, A. Liashenko, P. Piskorz, I. Komaromi, R. Gomperts, R. L. Martin, D. J. Fox, T. Keith, M. A. Al-Laham, C. Y. Peng, A. Nanayakkara, C. Gonzalez, M. Challacombe, P. M. W. Gill, B. Johnson, W. Chen, M. W. Wong, J. L. Andres, C. Gonzalez, M. Head-Gordon, E. S. Replogle, J. A. Pople, Gaussian 98, Revision A.6, Gaussian, Inc., Pittsburgh, PA, 1998.

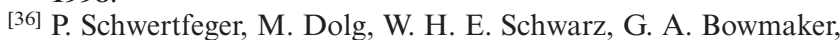
P. D. W. Boyd, J. Chem. Phys. 1989, 91, 1762.

${ }^{[37]}$ D. Andrae, U. Haeussermann, M. Dolg, H. Stoll, H. Preuss, Theor. Chim. Acta 1990, 77, 123.

${ }^{[38]} \mathrm{http}: / /$ www.theochem.uni-stuttgart.de/

${ }^{[39]}$ M. Kaupp, P. v. R. Schleyer, H. Stoll, H. Preuss, J. Am. Chem. Soc. 1991, 113, 1602.

[40] 40a C. W. Bauschlicher, H. Partridge, Chem. Phys. Lett. 1994, 231, 277. - 40b A. D. Becke, J. Chem. Phys. 1993, $98,5648$. - 40c A. D. Becke, Phys. Rev. A 1988, 38, 3098. - 40d C. Lee, W. Yang, R. G. Parr, Phys. Rev. B 1988, 37, 785. - 40e S. H. Vosko, L. Wilk, M. Nusair, Can. J. Phys. 1980, 58, 1200.

[41] [41a] W. Hehre, L. Radom, P. v. R. Schleyer, J. A. Pople, $A b$ Initio Molecular Orbital Theory, Wiley \& Sons, New York, 1986, p. 236. - ${ }^{[41 b]}$ T. M. Klapötke, A. Schulz, Quantenchemische Methoden in der Hauptgruppenchemie, Spektrum, Heidelberg, 1996; English version: T. M. Klapötke, A. Schulz, Quantum Chemical Methods in Main-Group Chemistry with an invited chapter by R. D. Harcourt, Wiley \& Sons, Chichester, 1998. - 4lc M. Otto, S. D. Lotz, G. Frenking, Inorg. Chem. $1992,31,3647$.

${ }^{[42]}$ A. E. Reed, L. A. Curtiss, F. Weinhold, Chem. Rev. 1988, 88, 899.

${ }^{[43]}$ A. E. Reed, R. B. Weinstock, F. Weinhold, J. Chem. Phys. 1985, 83, 735 .

${ }^{[44]}$ A. E. Smith, Acta Crystallogr. 1965, 18, 331.

${ }^{[45]}$ S. A. Litster, L. Mole, A. D. Redhouse, J. L. Spencer, Acta Crystallogr. 1992, C48, 913.

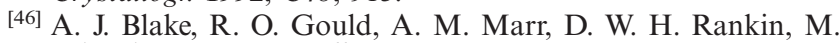
Schröder, Acta Crystallogr. 1989, C45, 1218.

[47] S. Ganguly, E. M. Georgiev, J. T. Mague, D. M. Roundhill, Acta Crystallogr. 1993, C49, 1168.

${ }^{[48]}$ P. A. Chaloner, S. Z. Dewa, P. B. Hitchcock, Acta Crystallogr. 1995, C51, 232.

Received March 13, 2000

[I00093] 